\title{
MEKANISME PELAKSANAAN STEMBUSACCORD PADA PEMILIHAN UMUM LEGISLATIF
}

\author{
Libasut Taqwa \\ Pusat Studi Kajian Timur Tengah dan Islam Pascasarjana Universitas Indonesia \\ Kampus UI, Kota Depok, Jawa Barat 16424 | Libasut.taqwa28I@gmail.com
}

\begin{abstract}
This article discusses about the mechanism and the implementationof stembusaccord in the legislative election in 1999 based on Undang-Undang No. 3 year 1999 under the political Islamic jurisprudence perspective. The result of the research shows that the incorporation of the remainder of votes or stembusaccord, which had been carried out by some Islamic parties in the legislative election in 1999, is the way to increase the number of conversional seatfrom the remainder of the constituent's votes. This provision had been done by the eight Islamic parties a week before the election in the form of an agreement. In the end, however, the provision, which was stipulated in Peraturan Pemerintah (Government Regulation) No. 33 year 1999, had been reduced by a disagreement between the political parties aboutits implementation in parliament. In a broader view, the stembusaccord system has a profitable and positive effect for the constituents in general. In Islamic legal theory, this is in line with principle of maqasid shariáh (purpose of Islamic law), since it realizing hifz al-ummah (protection to community). It can also be categorsized as hifz al-nafs (protection to soul), namely hurriyah al-syakhsiyyah (individual freedom) in the form of hurriyah al-ra'y (freedom to have argumentation) and musawah (equality) before the law and government.
\end{abstract}

Keywords: Stembusaccord, legislative election, political Islamic jurisprudence

Abstrak: Penelitian ini membahas tentang mekanisme pelaksanaan stembusaccord pada pemilu legislatif tahun 1999 menurut UndangUndang Nomor 3 tahun 1999, dan pelaksanaan stembusaccord pada pemilu legislatif 1999 menurut Undang-Undang Nomor 3 Tahun 1999 dalam perspektif figh siyasah. Dari hasil penelitian, ditemukan bahwa penggabungan sisa hasil pemilu atau stembusaccord yang 
dilakukan oleh partai Islam dalam pemilu legislatif pada tahun 1999 merupakan salah satu cara untuk menambah jumlah konversi kursi dari hasil sisa suara konstituen. Ketentuan ini oleh delapan partai Islam dilaksanakan seminggu sebelum pemilu dalam bentuk sebuah kesepakatan, walaupun pada akhirnya ketentuan yang diatur dalam Peraturan Pemerintah Nomor 33 Tahun 1999 tersebut direduksi oleh pertentangan antar partai politik pada tataran implementasi di parlemen. Dalam pandangan yang lebih luas, sistem stembusaccord ini memiliki efek positif yang menguntungkan bagi konstituen secara umum dan lebih mendekatkan kepada tujuan syari'at yaitu mewujudkan hifz al-ummah, dalam kategori hifz al-nafs yaitu hurriyah al-syakhsiyyah berupa hurriyah al-ra'y dan al-musyawah, yaitu persamaan hak di muka hukum dan pemerintahan.

Kata Kunci: Stembusaccord, pemilu legislatif, fiqh siyasah

\section{Pendahuluan}

Dalam perspektif sejarah, Indonesia telah mengalami sepuluh kali penyelenggaraan Pemilihan Umum (Pemilu), yaitu: pertama, Pemilu 1955, kedua Pemilu 1971, ketiga Pemilu 1977, keempat Pemilu 1982, kelima Pemilu 1987, keenam Pemilu 1992, ketujuh Pemilu 1997, kedelapan Pemilu 1999, kesembilan Pemilu 2004', dan kesepuluh Pemilu 2009.

Dari semua penyelenggaraan Pemilihan Umum tersebut, model dan sistem Pemilu yang diterapkan berbeda-beda sesuai dengan kondisi dan masa yang tengah terjadi. Ini juga tidak terlepas dari sistem politik yang dianut negara Indonesia dari masa ke masa. Hal ini menunjukan bahwa Pemilihan Umum menjadi penting karena dianggap sebagai lambang, sekaligus sebagai tolak ukur dari corak negara demokrasi karena hasil pemilihan umum yang diselenggarakan dalam suasana keterbukaan dengan kebebasan berpendapat dan kebebasan berserikat, dianggap mencerminkan dengan agak akurat partisipasi serta aspirasi masyarakat. ${ }^{2}$ Pemilu membawa pengaruh

' Titik Triwulan Tutik, Konstruksi Hukum Tata Negara Indonesia Pasca Amandemen UUD 1945, (Jakarta: Kencana, 20I I), 343

2 Miriam Budiarjo, Dasar-dasar IImu Politik, (Jakarta: PT. Gramedia Pustaka Utama, 2008), 46 I 
besar terhadap sistem politik suatu Negara. Melalui Pemilu, masyarakat berkesempatan berpartisipasi dengan kesempatan menunjukan para calon pemimpin dan penyaringan calon-calon tersebut. $^{3}$

Dari perjalanan panjang penyelenggaraan Pemilihan Umum tersebut, yang patut menarik perhatian adalah setelah Presiden Soeharto dilengserkan dari kekuasaannya sebagai Presiden pada tanggal 21 Mei 1998 dan jabatan Presiden digantikan oleh wakil Presiden Bacharudin Jusuf Habibie, karena disinilah letak perubahan besar sistem pemilu Indonesia setelah 32 tahun di bawah pemerintahan orde Baru. Atas desakan Publik, Pemilu yang baru atau dipercepat segera harus dilaksanakan, sehingga hasilhasil pemilu 1997 sebelumnya harus segera diganti. Pemilu akhirnya dilaksanakan pada 7 Juni 1999, atau 13 bulan masa kekuasaan Habibie. ${ }^{4}$ Pada saat itu, untuk sebagian alasan diadakannya pemilu adalah demi memperoleh pengakuan atau kepercayaan dari publik, termasuk dunia internasional, karena pemerintahan dan lembaga-lembaga lain yang merupakan produk pemilu 1997 sudah dianggap tidak dipercaya lagi dengan indeks kebebasan sipil dan hak politik yang rendah. ${ }^{5}$ Dalam hal ini, parlemen yang merupakan hasil pemilu 1997 juga secara otomatis dipangkas masa jabatannya menjadi hanya 3 tahun sejak pemilihan dilaksanakan.

Pemilu 1999 terlaksana berdasar atas UU Nomor 3 Tahun 1999 Tentang Pemilihan Umum yang diikuti banyak sekali partai politik. Ini dimungkinkan karena adanya kebebasan untuk mendirikan partai politik. Total ada 141 partai politik yang terdaftar di Departemen Kehakiman dan HAM, dengan 48 partai politik yang lolos verifikasi dan berhak mengikuti pemilu serta hanya 21 partai politik yang masuk parlemen. Dari total

\footnotetext{
3 Titik Triwulan, Konstruksi Hukum, 332

${ }^{4}$ Gotfridus Goris Seran, Kamus Pemilu Populer, (Yogyakarta: Graha Ilmu, 2013), 499

${ }^{5}$ Edward Aspinal And Marcus Mitzner ed., Problems of Democratisation in Indonesia; Election, Institutions and Society, (Singapore: Institute of Southeast Asian Studies, 20 I 0), 3 I
} 
209.389.000 jiwa terdapat 116.254.217 pemilih terdaftar, 105.786.6616 pemberi suara sah, dengan daerah pemilihan 32 provinsi. $^{7}$

Setelah pemilu dilaksanakan dan dilakukan penghitungan suara, yang menjadi hambatan adalah pembagian kursi di Parlemen selain hambatan-hambatan lain seperti unjuk rasa pada masa pemilu. Sistem Pemilu yang digunakan adalah proporsional dengan varian party-list dimana pemilih memberikan suara hanya kepada partai, dan selanjutnya partai akan memberikan suaranya kepada calon dengan nomor urut teratas. Selanjutnya Panitia Pemilihan Indonesia (PPI) melakukan pembagian kursi. Pada tahap ini, muncul masalah antar partai peserta pemilu khususnya pada pembagian kursi sisa. Saat itu, partai-partai beraliran Islam melakukan stembusaccord 8 (penggabungan sisa suara) untuk mendongkrak kursi di parlemen yang menurut perhitungan Panitia Pemilihan Indonesia (PPI) hanya memperoleh 40 dari 120 kursi. Di sisi lain, delapan partai beraliran Islam yaitu PPP (Partai Persatuan Pembangunan), PK (Partai Keadilan), PNU (Partai Nahdlatul Ummat), PKU (Partai Kebangkitan Umat), PBB (Partai Bulan Bintang), PUI (Partai Umat Islam), PSII 1905 (Parati Sarikat Islam Indonesia), dan Masyumi (Majelis Syuro Muslimin Indonesia) yang melakukan stembusaccord tersebut mengklaim

${ }^{6}$ Dalam penelitian ini penulis menggunakan hasil dari Marimin untuk menghitung stembusaccord karena memiliki penghitungan yang rinci dan jelas. Lihat. Marimin, Teknik dan Aplikasi Keputusan kriteria Majemuk, (Jakarta: Grasindo, 2005), I59. Bandingkan dengan KPU dalam Tempo Interaktif, 19 Maret 2004, dalam Widjanarko Puspoyo, Dari Soekarno Hingga Yudhoyono: Pemilu Indonesia 1955-2009, (Solo: Era Adicitra Intermedia, 2012), 290, juga dalam Bernhard Platzdasch, Islamism in Indonesia: Politics in the Emerging Democracy, (Singapore: Institute of Southeast Asian Studies, 2009), 345. http://www.amazon.com/lslamism-Indonesia-Politics-Emerging-Democracy/dp /9814279099, (diakses 17 Januari 20 I4).

${ }^{7}$ Gotfrindus, Kamus Pemilu. 499

${ }^{8}$ Stembusaccord atau Stembus-accord adalah istilah asli Belanda untuk suatu Provision atau ketentuan yang tercakup dalam sistem Pemilu perwakilan proporsional Terdaftar ( List PR) yang memungkinkan dua partai atau lebih atau pengelompokan yang berjuang melakukan kampanye secara terpisah untuk mencapai kesepakatan bahwa suara mereka akan digabungkan untuk tujuan pengalokasian kursi. Ini sama seperti lema dan Apparentment di Prancis dan Amerika latin. Lihat Gotfrindus Goris, Kamus Pemilu.., 651 
mampu memperoleh 53 dari 120 kursi sisa. Inilah yang menyebabkan terjadinya kebuntuan dalam proses pembagian kursi. Setelah dilakukan Voting oleh KPU, maka ditetapkan bahwa pembagian kursi di Parlemen ditetapkan tanpa menggunakan Stembusaccord. Hal ini menyebabkan delapan partai beraliran Islam walk out untuk memprotes kebijakan tersebut karena merasa tercurangi. Berbekal keputusan KPU tersebut PPI akhirnya melakukan pembagian kursi di parlemen hasil pemilu pada tanggal 1 September 1999 dengan tidak menggunakan hasil stembusaccord yang telah dilakukan partai Islam. Kekurangan akan karut-marutnya situasi sosial politik bangsa pada saat itu juga ikut mempengaruhi berbagai keputusan dan penghitungan hasil pemilihan umum ini. ${ }^{9}$

Apabila dilihat dari manfaatnya, stembusaccord sendiri akan menguntungkan partai-partai Islam karena akan menyelamatkan suara sebagai representasi hifz al-ummah agar perwakilan hak konstituen Islam terjamin dan terakomodasi dengan semestinya, juga memberikan jaminan terhadap hak-hak asasi manusia (hurriyah al-syakhsiyyah), jaminan mengeluarkan pendapat (hurriyah $a l-r a^{\prime} y$ ), dan hak untuk mendapatkan persamaan (al-musawah) di muka hukum dan pemerintahan. ${ }^{10}$ Stembusaccord inilah yang sangat penting menurut penulis, untuk mengetahui bagaimana mekanismenya menurut Undang-Undang Nomor 3 Tahun 1999 serta pelaksanaannya pada pemilu legislatif 1999 dalam perspektif Fiqh Siyasah.

Berdasarkan latar belakang tersebut, maka penulis menganggap perlu untuk melakukan penelitian dengan judul "Mekanisme Pelaksanaan Stembusaccord pada Pemilihan Umum Legislatif 1999 dalam Perspektif Figh Siyasah (Studi Kasus Partai Islam pada Pemilu Tahun 1999).

\footnotetext{
${ }^{9}$ Widjanarko Puspoyo, Dari Soekarno., 287

10 Muhakki, "Mekanisme Suara Terbanyak Bagi Pemilu Legislatif", Jurnal al-Daulah, Vol. 0 I Nomor 02 (Oktober 20 I I), 165
} 


\section{Pengertian Stembusaccord}

Pemilu 1999 diikuti oleh banyak sekali peserta (partai politik). Ini dimungkinkan karena adanya kebebasan untuk mendirikan partai politik. ${ }^{11}$ Peserta Pemilu kali ini adalah 48 partai, yang sudah jauh lebih sedikit dibandingkan dengan jumlah partai yang ada dan terdaftar di Departemen Kehakiman dan HAM, yakni 141 partai. ${ }^{12}$ Pemilu legislatif tahun 1999 menggunakan sistem proporsial terdaftar sebagaimana tercantum dalam UndangUndang Nomor 3 Tahun 1999 Tentang Pemilihan Umum pada pasal 1 ayat 7 yang menyatakan:

"Pemilihan Umum dilaksanakan dengan menggunakan sistem proporsional berdasarkan stelsel daftar."13

Menurut Kacung Maridjan, sistem pemilu (Electoral Sistem) merupakan salah satu instrumen kelembagaan penting di dalam negara demokrasi untuk mewujudkan kompetisi dalam kekuasaan, partisipasi masyarakat, dan jaminan hak-hak politik. ${ }^{14}$ Secara sederhana, sistem pemilu berarti instrumen untuk menerjemahkan perolehan suara di dalam Pemilu ke dalam kursikursi yang dimenangkan oleh partai atau calon. ${ }^{15}$ Dalam pemilu 1999, sistem proporsional stelsel daftar berarti sistem dimana presentasi kursi di badan perwakilan rakyat yang dibagi pada tiap-tiap partai politik, disesuaikan dengan persentase jumlah suara yang diperoleh pada tiap-tiap partai politik itu. Contohnya, jumlah pemilih yang sah dalam suatu pemilu adalah 1000 orang dan jumlah kursi di badan perwakilan rakyat ditentukan 10 kursi, berarti untuk satu orang wakil rakyat dibutuhkan suara 100 suara. Pembagian kursi di badan perwakilan tersebut tergantung kepada

\footnotetext{
"Ini sebagaimana tertulis dalam Undang-Undang Nomor 2 Tahun 1999 Tentang Partai Politik pada pasal 2 ayat I yang menyatakan:" sekurang-kurangnya 50 (lima puluh) orang warga negara Republik Indonesia yang telah berusia 2 I (dua puluh satu) tahun dapat membentuk Partai Politik."hal ini menunjukan bagaimana mudahnya mendirikan partai politik pada masa itu.

12 Gotfrindus Goris Seran, Kamus Pemilu., 500

13 Undang-Undang Nomor 3 Tahun 1999 Tentang Pemilihan Umum.

${ }^{14}$ Kacung Maridjan, Sistem politik Indonesia: Konsolidasi Demokrasi Pasca-Orde Baru, (Jakarta: Kencana, 20।0), 83

${ }^{15}$ lbid., 83
} 
berapa jumlah suara yang didapat setiap partai politik yang ikut pemilu. ${ }^{16}$ Namun, dalam pemilu 1999 konstituen hanya bisa memberikan suaranya dengan memilih partai politik bukan wakil rakyat secara langsung karena partai politik lah yang menentukan siapa yang akan duduk pada lembaga legislatif setelah mendapatkan suara dari konstituen. Sistem ini disebut sistem proporsional daftar tertutup atau party list yang melengkapi penjelasan Undang-Undang Nomor 3 Tahun 1999. Oleh karenanya mengenai sistem proporsional ini Miriam Budiarjo menyebut bahwa sistem Pemilu yang dipakai tidak terlalu berbeda dengan sistem Pemilu sebelumnya. ${ }^{17}$

Dalam sistem Pemilu 1999, diperbolehkan mekanisme penggabungan suara (Stembusaccord) antarpartai politik demi memperoleh kursi di DPR. Dari kesepakatan ini, partai dengan suara sah terbanyak yang berhak menerima tambahan suara. Kamus Pemilihan Umum menjelaskan bahwa stembusaccord merupakan istilah asli Belanda untuk suatu provision atau ketentuan yang tercakup dalam sistem Pemilu perwakilan proporsional terdaftar $(\text { List } P R)^{18}$ yang memungkinkan dua atau lebih partai atau pengelompokan yang berjuang melakukan kampanye secara terpisah untuk mencapai kesepakatan bahwa suara mereka akan digabungkan untuk tujuan pengalokasian kursi.

Lebih lengkap, perihal Pemilu 1999 Widjanarko Puspoyo memberikan definisi sebagai berikut: "stembusaccord adalah perjanjian pelimpahan sisa suara antar partai-partai peserta pemilu untuk menyerahkan sisa suara pada partai bersangkutan. Sisa suara yang dilimpahkan itu lazimnnya setelah pembagian kursi tahap pertama usai berdasarkan Bilangan Pembagi Pemilih

\footnotetext{
${ }^{16}$ Titik Triwulan Tutik, Konstruksi Hukum Tata Negara., 339

${ }^{17}$ Miriam Budiarjo, Dasar-dasar Ilmu Politik, 484

18 Party List (Daftar Partai) adalah sistem dimana konstituen hanya memberikan suaranya untuk partai politik bukan untuk calon. Sistem ini lazim digunakan dalam perwakilan berimbang (Proportional Representation)., lihat Gotfrindus Goris Seran, Kamus Pemilu., 369
} 
(BPP). ${ }^{19}$ Stembusaccord harus dilakukan seminggu sebelum pemungutan suara dan diketahui Panitia Pemilihan Indonesia (PPI). Misalnya dua partai atau lebih mengadakan stembusaccord, jika sisa suara setelah dihitung berdasarkan $\mathrm{BPP},{ }^{20}$ partai-partai yang melakukan stembusaccord akan mendapatkan kursi berdasarkan sisa suara terbanyak. Pada Pemilu 1999, delapan partai Islam, yakni PPP, PK, PNU, PKU, PBB, PUI, PSII 1905, dan Partai Masyumi serta partai beraliran Nasionalis yakni Partai Demokrasi Kasih Bangsa, Partai Bhineka Tunggal Ika, dan PADI (Partai Aliansi Demokrat) melakukan Stembusaccord untuk anggota DPR, DPRD I, DPRD II."21

Melihat pengertian di atas kiranya dapat dikatakan bahwa stembusaccord merupakan mekanisme penghitungan sisa suara hasil pemilu yang dapat digunakan apabila tahap pertama sebagai penghitungan normal suara dengan BPP telah terlaksana serta perjanjian (stembusaccord) penggabungan suara tersebut harus terlaksana seminggu sebelum dilakukan pemungutan suara.

\section{Dasar Hukum Penetapan Stembusaccord}

Pemilu legislatif tahun 1999 merupakan pemilu paling cepat yang dilaksanakan setelah pergantian rezim kepemimpinan. Sebelumnya, penyelenggaraan pemilu secara cepat juga pernah dilakukan Perdana Menteri Burhanudin Harahap yang hanya melakukan persiapan selama satu bulan sebelum pemilu 1955 setelah menggantikan Ali Sastroamidjoyo. Dengan dipercepatnya pemilu ini, maka seluruh elemen pemerintahan yang merupakan hasil dari pemilu 1997 seperti DPR, MPR, DPRD I dan II, juga Presiden dipangkas masa kekuasaannya yang seharusnya sampai

19 Bilangan Pembagi pemilih (BPP) adalah bilangan yang diperoleh dari hasil pembagian total jumlah suara sah yang diperoleh semua partai politik dalam pemilu dengan jumlah total kursi yang dialokasikan di suatu daerah pemilih., Ibid., 84

${ }^{20}$ Dalam Penelitian ini, penulis menggunakan jenis BPP pertama (dari dua jenis BPP yaitu BPP bagi kursi DPR dan kedua BPP bagi kursi DPRD) yang berarti bilangan yang diperoleh dari pembagian jumlah suara sah seluruh Partai Politik Peserta Pemilu secara nasional. Ibid., 84

${ }^{21}$ Widjanarko Puspoyo, Dari Soekarno hingga Yudhoyono., 282 
tahun 2003 demi meraih kepercayaan publik dan Internasional yang terlanjur menganggap produk pemilu 1997 adalah hasil dari kecurangan Orde Baru. ${ }^{22}$

Hanya 13 dari 18 bulan masa kepemimpinan Presiden Bacharudin Jusuf habibie setelah menggantikan Soeharto yang mengundurkan diri pada 21 Mei 1998, pemilu dilaksanakan setelah sebelumnya dibentuk Tim dari Depdagri yang diketuai Prof. Dr. M. Ryaas Rasyid (Rektor IIP Depdagri, Jakarta) untuk menyiapkan tiga draft UU untuk pemilu yaitu: RUU tentang partai politik, RUU tentang Pemilu, dan RUU tentang susunan dan kedudukan MPR, DPR, dan DPRD. ${ }^{23}$

Setelah RUU disahkan menjadi UU yaitu: UU Nomor 2 tahun 1999 tentang partai politik, UU nomor 3 tentang pemilihan umum, dan UU nomor 4 tentang susunan dan kedudukan MPR, DPR, dan DPRD, maka presiden membentuk KPU (Komisi Pemilihan Umum) untuk melaksanakan Pemilihan Umum yang anggotaanggotanya terdiri dari wakil partai politik dan wakil dari pemerintah dengan rincian 1 orang wakil dari masing-masing partai politik peserta pemilu dan 5 orang dari wakil pemerintah, dengan demikian KPU memiliki 53 anggota setelah ditambah 48 wakil dari partai yang ikut pemilu menurut Undang-undang nomor 3 tahun 1999. ${ }^{24}$

Masing-masing Undang-undang nomor 2, 3, dan 4 tahun 1999 disahkan dan diundangkan pada 1 Februari 1999, yang hanya berjarak empat bulan dari pemilihan umum tanggal 7 Juni 1999. Dalam perjalanannya, bagi Undang-undang nomor 3 tahun 1999 Tentang Pemilihan Umum ditetapkan lagi Peraturan Pemerintah (PP) nomor 33 tahun 1999 tentang Pelaksanaan Undang-undang nomor 3 Tahun 1999 tentang Pemilihan Umum, yang disahkan

\footnotetext{
22 lbid., 282

23 Titik Triwulan Tutik, Konstruksi Hukum Tata Negara., 366

${ }^{24}$ Pasal 9 ayat I UU nomor 3 tahun 1999 berbunyi: Keanggotaan KPU terdiri dari I (satu) orang wakil dari masing-masing partai politik peserta pemilihan umum dan 5 (lima) orang wakil pemerintah.
} 
dan diundangkan pada 19 Mei tahun 1999. PP ini berguna sebagai pelaksana teknis Undang-undang nomor 3 tersebut. Secara khusus PP (Peraturan Pemerintah) nomor 33 tahun 1999 dalam konsideransnya diterangkan:

"Bahwa untuk melaksanakan ketentuan pasal 8425 UndangUndang Nomor 3 Tentang Pemilihan Umum, perlu menetapkan Peraturan Pemerintah tentang Pelaksanaan Undang-Undang Nomor 3 Tahun 1999 Tentang Pemilihan Umum."

Ini juga sesuai dengan Undang-Undang Dasar 1945 sebelum amandemen Pasal 5 ayat 2 (dua) yang menyatakan:

"Presiden menetapkan Peraturan Pemerintah untuk menjalankan Undang-Undang sebagaimana mestinya." 26

Dengan kata lain, ditetapkannya PP nomor 33 Tahun 1999 tidak lain hanya untuk melengkapi UU Nomor 3 Tahun 1999 apabila terdapat hal yang belum cukup diatur, serta juga merupakan amanat UUD 1945 kepada presiden untuk menetapkannya apabila dirasa perlu, sehingga dapat dikatakan tidak bertentangan dengan Undang-undang. Dalam PP nomor 33 Tahun 1999 inilah letak dasar hukum dari stembusaccord, yang secara khusus diatur dalam BAB VII Penggabungan Suara pada Pasal 36 ayat 1 sampai ${ }^{32}$ sebagai berikut:

(1) Dua atau lebih Partai Politik Peserta Pemilu dapat mengikatkan diri dalam kesepakatan tentang Penggabungan suara di daerah Tingkat ${ }^{28}$ dan Tingkat II ${ }^{29}$ untuk penentuan

${ }^{25}$ Bunyi pasal 84 UU nomor 3 tahun 1999 adalah: Segala sesuatu yang belum cukup diatur di dalam Undang-undang ini, Pasal diatur dengan Peraturan Pemerintah sesuai kebutuhan.

26 Undang-undang Dasar 1945 pasal 5 Ayat 2 (dua) berbunyi: Presiden menetapkan Peraturan Pemerintah untuk menjalankan Undang-undang sebagaimana mestinya.

${ }^{27}$ Peraturan Pemerintah Nomor 33 Tahun 1999 Tentang Pelaksanaan Undang-undang Nomor 3 tahun 1999 Tentang Pemilihan Umum.

${ }^{28}$ Daerah Tingkat I adalah daerah pemilihan untuk DPR, dalam hal ini total dari seluruh provinsi di Indonesia pada 1999 sebagai daerah pemilihannya, Pasal 2 ayat 2 point (a) UU Nomor 3 Tahun 1999.

29 Daerah Tingkat II adalah daerah pemilihan untuk DPRD I, dalam hal ini daerah Tingkat I merupakan satu daerah pemilihan (Propinsi).Pasal 2 ayat 3 point (b) UU Nomor 3 tahun 1999. 
calon terpilih anggota DPR, DPRD I Propinsi, dan DPRD II Kota/Kabupaten.

(2) Kewenangan melakukan kesepakatan sebagaimana dimaksud dalam ayat (1) berada pada Dewan Pimpinan Pusat Partai Politik Peserta Pemilu dan kewenangan tersebut dapat didelegasikan kepada Dewan Pimpinan Daerah Partai Politik yang bersangkutan.

(3) Kesepakatan sebagaimana dimaksud dalam ayat (1) sudah harus diumumkan selambat-lambatnya 7 (tujuh) hari sebelum pemungutan suara dan tembusannya disampaikan kepada PPI, PPD I, PPD II, dan PANWAS sesuai dengan tingkatannya.

Dalam penjelasannya, yang dimaksud dengan "kesepakatan tentang penggabungan suara" adalah yang dikenal dengan istilah Stembusaccord. Kesepakatan tersebut berlaku di setiap daerah Tingkat I dan Tingkat II sekalipun di daerah yang bersangkutan di antara partai Politik yang mengikatkan diri dalam kesepakatan ada yang tidak mempunyai calon. ${ }^{30}$

PPI (Panitia Pemilihan Umum) sebagaimana yang disebutkan sebagai juga termasuk elemen Pemilu tempat diumumkan dan disampaikannya kesepakatan stembusaccord, adalah Panitia Pemilihan Umum yang dibentuk oleh KPU untuk membantu KPU dalam pelaksanaan Pemilihan Umum yang ada dari tingkat pusat sampai di tingkat terkecil yang berturut-turut bernama PPD I (Panitia Pemilihan Daerah Tingkat I Propinsi), PPD II (panitia Pemilihan Daerah Tingkat II Kota/Kabupaten), PPK (Panitia Pemilihan Kecamatan), serta PPS (Panitia Pemungutan Suara) di setiap daerah pemilihan. Panitia ini memiliki tugas dan wewenang sebagai berikut: ${ }^{1}$

30 Penjelasan Atas Peraturan Pemerintah Nomor 33 Tahun 1999 Tentang Pelaksanaan Undangundang Nomor 3 tahun 1999 Tentang Pemilihan Umum.

31 Undang-Undang Nomor 3 Tahun 1999 Tentang Pemilihan Umum berturut-turut, pasal I3, pasal 14, dan pasal 16. 
a. Membentuk serta mengkoordinasikan Pemilihan Umum sesuai daerah tingkatannya

b. Menetapkan nama-nama anggota legislatif di setiap daerah tingkatan

c. Melaksanakan pemilihan umumlegislatif

d. Menghitung hasil suara hasil pemilihan umum

\section{Mekanisme Yuridis Pelaksanaan Stembusaccord oleh Partai Politik}

Berdasarkan ketentuan yang telah diatur dalam PP Nomor 33 Tahun 1999 tentang Pelaksanaan Undang-Undang Nomor 3 Tahun 1999, serta menurut beberapa literatur mengenai pengertian stembusaccord, maka setidaknya dapat penulis jabarkan bagaimana mekanisme pelaksanaan stembusaccord sebagai berikut:

a. Dua atau lebih Partai Politik mengadakan sebuah kesepakatan mengenai penggabungan sisa suara hasil pemilu.

b. Kewenangan dalam penentuan kesepakatan penggabungan tersebut ditentukan oleh Dewan Pimpinan Pusat Partai yang bertempat di Ibu Kota Negara serta dapat mendelegasikannya kepada Dewan Pimpinan Daerah Partai Politik yang bersangkutan.

c. Kesepakatan tersebut harus dilakukan sebelum pemungutan suara berlangsung dan sudah harus diumumkan selambatlambatnya 7 (tujuh) hari sebelum pemungutan suara dan tembusannya disampaikan kepada PPI, PPD I, PPD II, dan PANWAS sesuai dengan tingkatannya.

d. Sesuai dengan Rapat Pleno KPU pada Bulan Mei 1999, kesepakatan stembusaccord berbentuk "SK" (Surat Keputusan) yang dibuat oleh masing-masing Partai Politik yang melakukan stembusaccord dan harus ditandatangani oleh ketua Umum dan Sekjen (Sekretaris Jenderal) masing-masing partai sebelum diserahkan kepada KPU. ${ }^{32}$

32 Koran Republika, I Juli 1999, http://groups.yahoo.com/heo/groupsFreemail/conversations/ Topics /2779, diakses 27 Desember 2013 
e. Setelah berkas diterima dan dinyatakan telah sesuai dengan syarat-syarat stembusaccord oleh KPU, maka partai politik yang telah bersepakat dapat mengimplementasikan stembusaccord hasil kesepakatan tersebut setelah pemilu dilaksanakan pada proses penghitungan sisa suara.

f. Pada proses penghitungan sisa suara, sisa suara yang dilimpahkan itu lazimnnya setelah pembagian kursi tahap pertama usai berdasarkan Bilangan Pembagi Pemilih (BPP).

g. Setelah penghitungan sisa suara, dalam kesepakatan ini, partai dengan suara sah terbanyak dari partai-partai yang melakukan stembusaccord tadilah yang berhak menerima tambahan suara.

h. Sisa suara dari partai politik yang mengadakan stembusaccord itu akan menambah jumlah kursi bagi partai politik yang pada pembagian pertama tidak mendapat kursi, atau mendapat jumlah kursi yang kecil, ataupun sisa suara dari partai yang kecil diberikan kepada partai yang mendapat kursi banyak supaya menambah jumlah kursinya, tergantung pada kesepakatan antar partai politik dalam kesepakatan stembusaccord tersebut.

Dari ketentuan yang telah diatur tersebut, partai-partai Islam yang melakukan stembusaccord melakukan kesepakatan sesuai dengan aturan yang berlaku dan menyerahkan berkas kesepakatan kepada KPU pada 1 Juni 1999.33 Hasil dari stembusaccord akan dihitung apabila telah melalui tahap I Bilangan Pembagi Pemilih, setelah itu dihitung sisa suara yang tersisa untuk kemudian digabungkan.

Porsi yang akan diperoleh masing-masing Organisasi Partai Politik (OPP) untuk anggota DPR yaitu jumlah seluruh suara pemilih yang sah dalam wilayah Indonesia dibagi $462^{34}$ kursi akan

33 Ibid.

34 Pasal I I UU Nomor 4 Tahun 1999:

(2) DPR terdiri atas :

a. anggota partai politik hasil Pemilihan Umum;

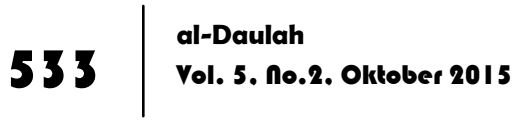


menjadi Bilangan Pembagi Pemilih (BPP). Sebagai contoh sederhana umpamanya jumlah seluruh suara untuk DPR RI 46.200.000 maka BPP menjadi 46.200.000 dibagi 462 sama dengan 100.000. Dengan BPP 100.000 maka perolehan suara setiap partai politik untuk DPR RI berarti harus dibagi dengan BPP 100.000 dan akan menentukan berapa banyak kursi yang akan diperoleh setiap partai politik. Dan bagi partai politik yang mengadakan stembusaccord, maka sisa suara dari parpol yang mengadakan stembusaccord itu akan menambah jumlah kursi bagi partai politik yang pada pembagian pertama tidak mendapat kursi, atau mendapat jumlah kursi yang kecil, ataupun sisa suara dari partai yang kecil diberikan kepada partai yang mendapat kursi banyak supaya menambah jumlah kursinya, tergantung pada kesepakatan antar partai politik dalam kesepakatan stembusaccord tersebut. ${ }^{35}$

Pada pemilihan umum tahun 1999, Dari total 209.389.000 jiwa terdapat 116.254.217 pemilih terdaftar, 105.786 .661 pemberi suara sah, dengan daerah pemilihan 32 Provinsi.Dalam hal ketentuan ini, delapan partai politik Islam menyatakanbahwa untuk memperebutkan sisasuara, setelah tahap penghitungan pertama dengan BPP,maka setelah tahap kedua penghitungan sisa hasil suara, cukup dengan langsung melihat di antara partai politikpartai politik yang ada, mana yang urutan sisa suaranya paling besar. (Jika misalnya, ada 2 partai yang menggabungkan suaranya dan bisa mendapatkan satu kursi, maka mereka (partai) sendiri yang akan menentukan siapa yang akan mendapatkan jatah kursi tersebut). ${ }^{36}$

b. anggota $A B R I$ yang diangkat.

(3) Jumlah Anggota DPR adalah 500 orang dengan rincian

a. anggota partai politik hasil Pemilihan Umum, sebanyak 462 orang;

b. anggota ABRI yang diangkat, sebanyak 38 orang.

35 Jimmi Mohammad Ibrahim, "Kalbar Pasca Pemilu," dalam http://wnw.reocities.com/Area5 I Nault//534/juni/08/berita37036.htm (27 Desember 20 I3)

36 Komunitas Informasi Terbuka, "runyamnya stembus accord," dalam http://www.minihub.org/siarlist/28.htm/ (27 Desember2012) 
Contoh Mekanisme perhitungannya adalah sebagai berikut dalam perhitungan, rumus $^{37}$ :

Bilangan Pembagi Pemilih dalam perwakilan berimbang (proporsional representation) sering diistilahkan dengan Quota (Q). Jumlah Suara Sah (JSS) yang diperoleh semua partai politik dalam pemilu dinamakan Vote (V). Jumlah Total Kursi (JTK) yang dialokasikan di suatu daerah pemilihan disebut Seat (S). Dengan demikian rumus yang muncul adalah $\mathrm{Q}=\mathrm{V} / \mathrm{S}$. atau $\mathrm{V}$ dibagi dengan $S$ untuk memperoleh $Q .{ }^{38}$ Setelah memperoleh BPP, maka dilakukan penghitungan perolehan kursi di parlemen dengan rumus N1 sebagai lambang jumlah kursi yang diperoleh suatu partai politik pada tahap I, A sebagaijumlah suara sah yang diperoleh partai politik tersebut, sehingga rumusnya $\mathrm{N} 1=\mathrm{A} / \mathrm{Q}$ (BPP) atau A dibagi dengan $Q$ untuk memperoleh N1.Setelah itu untuk tahap II pembagian sisa suara digunakan N2 sebagai lambang pembagian suara tahap II, dengan formula membagikan jumlah sisa kursi yang belum terbagi pada partai peserta pemilu yang memperoleh sisa suara terbanyak. ${ }^{39}$

Contoh : Suara sah secara nasional yang dihasilkan dalam suatu pemilu adalah 100.000.000 suara, dengan total 462 kursi DPR yang diperebutkan. Partai A (memperoleh 10.000 .000 suara), partai B (15.000.000 suara), dan partai C (30.000.000 suara) yang berjumlah total 3 partai bersepakat sebelum pemilu untuk melakukan stembusaccord pada penghitungan sisa hasil suara, maka cara menghitungnya sebagai berikut:

$$
\begin{aligned}
& Q= \\
& Q= \\
& Q=216.450
\end{aligned}
$$

Jadi BPP pada Pemilu legislatif adalah 216.450. setelah memperoleh BPP, maka dilanjutkan untuk menghitung pembagian kursi tahap I.

\footnotetext{
${ }^{37}$ Gotfrindus Goris Seran, Kamus Pemilu., 84

38 lbid., 84

${ }^{39}$ Titik Triwulan, Konstruksi Hukum Tata Negara, 390
} 


$$
\begin{aligned}
& \mathrm{N} 1= \\
& \mathrm{N} 1= \\
& \mathrm{N} 1=46 \text { (setelah dibulatkan) }
\end{aligned}
$$

Berdasarkan perhitungan ini, maka partai A memperoleh 46 kursi(Cara penghitungan ini berlaku juga untuk partai B, yang melakukan stembusaccord)

$\mathrm{N} 1=$

$\mathrm{N} 1=$

N1 = 69 (setelah dibulatkan)

Maka partai B memperoleh 69 kursi. Hal yang sama juga dilakukan pada partai C. (setelah dihitung, partai C menghasilkan 138 kursi. Setelah itu dilanjutkan tahap penghitungan sisa suara atau tahap II, yaitu:

Setelah dibagi dan mendapatkan 46 kursi, partai A masih memiliki sisa suara sebesar 43.300 suara. Ini diperoleh dari hasil 10.000.000 suara dikurangi 9.956.700. Hasil 9.956.700 ini diperoleh dari 46 (jumlah kursi awal) dikalikan dengan 216.450. Demikian juga dengan partai B masih memiliki sisa suara sebesar 64.950. ini didapatkan dari hasil 15.000 .000 suara dikurangi 14.935 .050 yang diperoleh dari 69 (sebagai jumlah kursi) dikalikan dengan 216.450. sisa suara partai $C$ yaitu 129.900 suara.

Kemudian ketiga sisa suara partai yang melakukan stembusaccord tadi digabungkan:

$43.300+64.950+129.900=238.150$ (jumlah suara setelah digabungkan)

Pada tahap akhir, jumlah suara ini dibagi lagi dengan BPP awal 216.450

$\mathrm{N} 2=$ Sisa suara $/ \mathrm{BPP}$

$\mathrm{N} 2=238.150 / 216.450=1,1$. Hasil ini dibulatkan menjadi 1 (satu). Jadi, hasil stembusaccord atau penggabungan sisa suara dari partai A, Partai B, dan Partai C mendapatkan 1 (satu) kursi. Satu kursi ini akan diperuntukkan antara ketiga partaitersebut sesuai dengan kesepakatankepada partai mana kursi akan dialokasikan. 


\section{Implementasi Stembusaccord dalam Perolehan Kursi di Parlemen}

Pelaksanaan pemilihan umum tahun 1999 tidak seperti pemilu pada tahun sebelumnya karena dari segi peserta, pemilu diikuti oleh banyak partai. Hal ini menyebabkan terjadinya perebutan kursi parlemen antarpartai dan juga menimbulkan permasalahan tersendiri dalam penentuan jumlah kursi anggota DPR maupun anggota MPR termasuk di dalamnya permasalahan apakah menggunakan hasil dari mekanisme stembusaccord atau tidak. ${ }^{40}$

Pemilihan umum berlangsung tanpa kendala yang berarti, masalah muncul ketika pemilu terhambat pada tahap penghitungan suara dan pembagian kursi DPR dan DPRD I dan II karena sempat mengalami hambatan antar kekuatan partai politik. pada tahap penghitugan suara, ada 27 partai politik menengah yang tidak menyetujui dan menolak menandatangani berkas berita acara penghitungan suara dengan dalih pemilu belum jujur dan adil, masih banyak kecurangan. untuk lebih lengkapnya, berikut nama-nama partai politik tersebut:

Tabel 1.1

Partai Politik Yang tidak menandatangani hasil Pemilu 199941

\begin{tabular}{|l|l|l|l|}
\hline No. & Nama Partai & Jumlah Suara & $\mathbf{\%}$ \\
\hline 1. & Partai Keadilan & 1.436 .585 & $1,36 \%$ \\
\hline 2. & PNU & 679.179 & $0,64 \%$ \\
\hline 3. & PBI & 364.291 & $0,34 \%$ \\
\hline 4. & PPDI & 655.052 & $0,62 \%$ \\
\hline 5. & PPIM & 456.718 & $0,43 \%$ \\
\hline 6. & PNI Supeni & 311.137 & $0,43 \%$ \\
\hline 7. & Krisna & 369.719 & $0,29 \%$ \\
\hline 8. & Partai KAMI & 289.498 & $0,35 \%$ \\
\hline 9. & PKD & 216.675 & $0,27 \%$ \\
\hline 10. & PAY & 213.979 & $0,20 \%$ \\
\hline
\end{tabular}

${ }^{40}$ Marimin, Teknik dan Aplikasi pengambilan Keputusan kriteria Majemuk, I 57

41 Abdul Mukhtie Fadjar, Partai Politik dalam Perkembangan Ketatanegaraan Indonesia, (Malang:Setara Press, 20I2), 136 


\begin{tabular}{|l|l|l|l|}
\hline 11. & Partai MKGR & 204.204 & $0,20 \%$ \\
\hline 12. & PIB & 192.712 & $0,19 \%$ \\
\hline 13. & Partai SUNI & 180.167 & $0,18 \%$ \\
\hline 14. & PNBI & 149.136 & $0,17 \%$ \\
\hline 15. & PUDI & 140.980 & $0,14 \%$ \\
\hline 16. & PBN & 111.629 & $0,13 \%$ \\
\hline 17. & PKM & 104.385 & $0,11 \%$ \\
\hline 18. & PND & 96.984 & $0,10 \%$ \\
\hline 19. & PADI & 85.838 & $0,09 \%$ \\
\hline 20. & PRD & 78.730 & $0,08 \%$ \\
\hline 21. & PPI & 63.934 & $0,07 \%$ \\
\hline 22. & PID & 62.901 & $0,06 \%$ \\
\hline 23. & Murba & 62.006 & $0,08 \%$ \\
\hline 24, & SPSI & 61.105 & $0,06 \%$ \\
\hline 25. & PUMI & 49.839 & $0,06 \%$ \\
\hline 26. & PSP & 49.807 & $0,05 \%$ \\
\hline 27. & PARI & 54.790 & $0,05 \%$ \\
\hline
\end{tabular}

Karena ada penolakan, dokumen rapat KPU kemudian diserahkan oleh pimpinan KPU Rudini kepada Presiden BJ. Habibie. Oleh presiden, hasil rapat KPU tersebut kemudian diserahkan kepada Panwaslu (Panitia Pengawas Pemilu). Panwaslu diberi tugas meneliti keberatan yang telah diajukan oleh partai yang tidak bersedia menandatangani hasil pemilu 1999. Alhasil, Panwaslu memberikan rekomendasi bahwa pemilu 1999 adalah sah dan tidak ada kendala berarti. Dan tidak ada alasan untuk diadakan pemilu ulang, sehingga pada tanggal 26 Juli, ${ }^{42}$ presiden menyatakan hasil final pemilu adalah sah.

Selanjutnya, Panitia Pemilihan Indonesia (PPI) melakukan pembagian kursi, disinilah terjadi pro kontra antar partai politik, yaitu yang menginginkan menggunakan sistem stembusaccord di satu sisi, dan yang tidak menginginkannya di sisi lain. Ketika terjadi perdebatan alot tersebut maka PPI menyerahkannya 
kepada KPU untuk diselesaikan. Oleh KPU, perbedaan pendapat tersebut diselesaikan dengan cara Voting dengan dua opsi: Pertama, pembagian kursi sisa dihitung dengan menggunakan suara stembusaccord. Kedua, pembagian kursi tanpa menggunakan stembusaccord, mayoritas suara yaitu 43 suara (jumlah anggota KPU ada 53 orang) mendukung pembagian kursi dengan opsi kedua tapa menggunakan stembusaccord. Berbekal keputusan KPU itulah maka PPI akhirnya dapat melakukan pembagian kursi pada tanggal 1 September 1999 tanpa menggunakan sistem stembusaccord dengan lima partai besar yang menjadi pemenang yaitu: PDI Perjuangan, Golkar, Partai Kebangkitan Bangsa (PKB), Partai Persatuan Pembangunan (PPP), dan Partai Amanat Nasional (PAN). Kelima partai ini memborong 417 kursi DPR atau 90,26 \% dari 462 kursi yang diperebutkan. ${ }^{43}$ Untuk mengetahui cara penghitungan dengan menggunakan sistem stembusaccord, berikut mekanisme penghitungannya:

Sebagaimana yang telah dijelaskan sebelumnya, jumlah pemilih sebesar 105.786.638 dengan kursi yang diperebutkan oleh partai sebesar 462 kursi. Kursi yang ada di DPR secara keseluruhan berjumlah 500 kursi dimana TNI/POLRI telah mendapatkan kursi di DPR sebanyak 38 kursi tanpa harus mengikuti pemilihan umum, sehingga jumlah kursi yang diperebutkan oleh partai-partai yang ikut pemilu hanya 462 kursi. Sebagaimana penggunaan rumus penghitungan pada pembahasan sebelumnya, maka perhitungan jumlah anggota DPR RI pada tahun 1999 adalah sebagai berikut: ${ }^{44}$

Pembagi $=288.975$

Dari jumlah perolehan suara diperoleh kursi sebagai berikut:

Tabel 1.2

\begin{tabular}{|l|l|l|l|l|}
\hline No & \multicolumn{1}{|c|}{ Nama Partai } & $\begin{array}{c}\text { Perolehan } \\
\text { Suara }\end{array}$ & Kursi & $\begin{array}{c}\text { Sisa } \\
\text { Suara }\end{array}$ \\
\hline 1. & PDI Perjuangan & 35.689 .073 & 155 & 197.948 \\
\hline
\end{tabular}

${ }^{43}$ Ibid., 286-287

${ }^{44}$ Ibid., I 58- 163 


\begin{tabular}{|c|c|c|c|c|}
\hline 2. & Partai Golongan Karya & 23.741 .758 & 103 & 157.333 \\
\hline 3. & $\begin{array}{l}\text { Partai Persatuan } \\
\text { Pembangunan }\end{array}$ & 11.329 .905 & 49 & 110.130 \\
\hline 4. & Partai kebangkitan Bangsa & 13.336 .982 & 58 & 56.431 \\
\hline 5. & Partai Amanat Nasional & 7.528 .956 & 32 & 201.756 \\
\hline 6. & Partai Bulan Bintang & 2.049 .708 & 8 & 217.908 \\
\hline 7. & Partai Keadilan & 1.936 .565 & 6 & 62.715 \\
\hline 8. & $\begin{array}{l}\text { Partai Keadilan dan } \\
\text { Persatuan }\end{array}$ & 1.065 .686 & 4 & 149.756 \\
\hline 9. & $\begin{array}{l}\text { Partai Demokrasi Kasih } \\
\text { Bangsa }\end{array}$ & 550.851 & 2 & 92.901 \\
\hline 10. & Partai Nahdlatul Umat & 658.063 & 2 & 200.119 \\
\hline 11. & Partai Bhinneka Tunggal Ika & 345.292 & 1 & 125.317 \\
\hline 12. & Partai Demokrasi Indonesia & 655.049 & 2 & 197.009 \\
\hline 13. & Partai Kebangkitan Umat & 300.064 & 1 & 71.089 \\
\hline 14. & Partai Serikat Islam Indonesia & 375.920 & 1 & 146.945 \\
\hline 15. & PNI Front Marhaenis & 363.397 & 1 & 134.422 \\
\hline 16. & Partai IPKI & 327.301 & 1 & 98.326 \\
\hline 17. & PNI Massa Marhaen & 345.720 & 1 & 116.745 \\
\hline 18. & Parati Persatuan & 550.808 & 2 & 92.858 \\
\hline 19. & Partai Daulat Rakyat & 429.854 & 1 & 200.879 \\
\hline 20. & Partai Kristen Nasional & 369.446 & 1 & 140.471 \\
\hline 21. & Partai Nasional Indonesia & 377.137 & 1 & 108.162 \\
\hline 22. & Partai KAMI & 289.489 & 1 & 60.514 \\
\hline 23. & Partai Umat Islam & 269.309 & 1 & 40.334 \\
\hline 24. & Partai Masyumi & 456.718 & 1 & 227.743 \\
\hline 25. & PADI & 85.838 & 0 & 85.838 \\
\hline 26. & Partai Masyumi Baru & 151.589 & 0 & 151.589 \\
\hline 27. & Partai Abul Yatama & 213.979 & 0 & 213.979 \\
\hline 28. & Partai Kebangsaan Merdeka & 104.385 & 0 & 104.385 \\
\hline 29. & Partai Rakyat Demokratik & 78.730 & 0 & 78.730 \\
\hline 30. & PSII 1905 & 152.787 & 0 & 152.787 \\
\hline 31. & Partai Katolik Demokrat & 216.675 & 0 & 216.675 \\
\hline 32. & Partai Pilihan Rakyat & 40.517 & 0 & 40.517 \\
\hline 33. & Partai Rakyat Indonesia & 45.290 & 0 & 45.290 \\
\hline 34. & Partai Solidaritas Pekerja & 49.807 & 0 & 49.807 \\
\hline
\end{tabular}




\begin{tabular}{|l|l|l|l|l|}
\hline 35. & Partai Republik & 208.157 & 0 & 208.157 \\
\hline 36. & Partai Islam Demokrat & 62.901 & 0 & 62.901 \\
\hline 37. & Partai Murba & 62.006 & 0 & 62.006 \\
\hline 38. & PUDI & 140.980 & 0 & 140.980 \\
\hline 39. & Partai Buruh Nasional & 111.629 & 0 & 111.629 \\
\hline 40. & Partai MKGR & 204.204 & 0 & 204.204 \\
\hline 41. & Partai Cinta Damai & 168.087 & 0 & 168.087 \\
\hline 42. & Partai SPSI & 61.095 & 0 & 61.095 \\
\hline 43. & PNBI & 149.136 & 0 & 149.136 \\
\hline 44. & Partai SUNI & 180.167 & 0 & 180.167 \\
\hline 45. & Partai Nasional Demokrat & 96.984 & 0 & 96.984 \\
\hline 46. & $\begin{array}{l}\text { Partai Umat Muslimin } \\
\text { Indonesia }\end{array}$ & 49.839 & 0 & 49.839 \\
\hline 47. & Partai Pekerja Indonesia & 63.930 & 0 & 63.930 \\
\hline 48. & Partai Indonesia Baru & 192.712 & 0 & 192.712 \\
\hline JUMLAH & 105.786 .638 & 435 & \\
\hline
\end{tabular}

Kemudian setelah proses pemilu selesai ada beberapa partai yang melakukan stembusaccord yang diakui KPU ada dua dengan asumsi bahwa kursi hasil stembusaccord diperuntukkan bagi partai yang memiliki sisa suara terbanyak.

\section{Stembusaccord I}

Tabel 1.3

\begin{tabular}{|l|l|}
\hline \multicolumn{1}{|c|}{ Partai } & \multicolumn{1}{c|}{ Sisa Suara } \\
\hline PUI & 40.334 \\
\hline PKU & 71.089 \\
\hline PK & 62.715 \\
\hline PNU & 200.199 \\
\hline PSII 1905 & 152.787 \\
\hline PPP & 110.130 \\
\hline Partai Masyumi & 227.743 \\
\hline PBB & 217.908 \\
\hline JUMLAH & 1.082 .905 \\
\hline SISA & 167.005 \\
\hline
\end{tabular}


Pada stembusaccord I dengan jumlah 1.082.905 mendapat jatah empat kursi yang seharusnya diperuntukkan kepada partai Masyumi, tetapi karena kesepakatan antara partai Masyumi dengan partai PBB jumlah kursi yang didapat oleh partai Masyumi diberikan kepada PBB. 45

Selanjutnya stembusaccord II

Pada Pemilu 1999 ada dua kelompok partai yang dinyatakan lolos persyaratan stembusaccord, seperti pada pembahasan sebelumnya, selain 8 partai Islam juga terdapat 2 partai lagi yaitu Partai Demokrasi Kasih Bangsa dan Partai Bhineka Tunggal Ika serta Partai Aliansi Demokrat (PADI), sehingga harus diikutkan dalam rangkaian penentuan jumlah kursi sebagai berikut: (Tabel 1.4)

\begin{tabular}{|l|l|}
\hline \multicolumn{1}{|c|}{ Partai } & \multicolumn{1}{c|}{ Sisa Suara } \\
\hline Partai Demokrasi Kasih Bangsa & 92.901 \\
\hline Partai Bhineka Tunggal Ika & 125.317 \\
\hline Partai Aliansi Demokrat (PADI) & 85.838 \\
\hline JUMLAH & 304.056 \\
\hline SISA & 75.081 \\
\hline
\end{tabular}

Dari stembusaccord kedua ini mendapatkan satu kursi yang diperuntukan bagi Partai Bhineka Tunggal Ika

Tabel 2.1. Setelah stembusaccord,

\begin{tabular}{|c|l|l|l|l|}
\hline No & \multicolumn{1}{|c|}{ Nama Partai } & \multicolumn{1}{c|}{$\begin{array}{c}\text { Perolehan } \\
\text { Suara }\end{array}$} & \multicolumn{1}{|c|}{ Kursi } & Sisa Suara \\
\hline 1. & PDI Perjuangan & 35.689 .073 & 155 & 197.948 \\
\hline 2. & Partai Golongan Karya & 23.741 .758 & 103 & 157.333 \\
\hline 3. & $\begin{array}{l}\text { Partai Persatuan } \\
\text { Pembangunan }\end{array}$ & 11.329 .905 & 49 & - \\
\hline 4. & Partai kebangkitan Bangsa & 13.336 .982 & 58 & 56.431 \\
\hline 5. & Partai Amanat Nasional & 7.528 .956 & 32 & 201.756 \\
\hline 6. & Partai Bulan Bintang & 2.049 .708 & $13^{*}$ & 166.925 \\
\hline 7. & Partai Keadilan & 1.936 .565 & $6^{*}$ & - \\
\hline
\end{tabular}




\begin{tabular}{|c|c|c|c|c|}
\hline 8. & $\begin{array}{l}\text { Partai Keadilan dan } \\
\text { Persatuan }\end{array}$ & 1.065 .686 & 4 & 149.756 \\
\hline 9. & $\begin{array}{l}\text { Partai Demokrasi Kasih } \\
\text { Bangsa }\end{array}$ & 550.851 & $2^{*}$ & - \\
\hline 10. & Partai Nahdlatul Umat & 658.063 & $2^{*}$ & - \\
\hline 11. & Partai Bhinneka Tunggal Ika & 345.292 & $2^{*}$ & 75.081 \\
\hline 12. & Partai Demokrasi Indonesia & 655.049 & 2 & 197.009 \\
\hline 13. & Partai Kebangkitan Umat & 300.064 & $1^{*}$ & - \\
\hline 14. & $\begin{array}{l}\text { Partai Serikat Islam } \\
\text { Indonesia }\end{array}$ & 375.920 & 1 & 146.945 \\
\hline 15. & PNI Front Marhaenis & 363.397 & 1 & 134.422 \\
\hline 16. & Partai IPKI & 327.301 & 1 & 98.326 \\
\hline 17. & PNI Massa Marhaen & 345.720 & 1 & 116.745 \\
\hline 18. & Parati Persatuan & 550.808 & 2 & 92.858 \\
\hline 19. & Partai Daulat Rakyat & 429.854 & 1 & 200.879 \\
\hline 20. & Partai Kristen Nasional & 369.446 & 1 & 140.471 \\
\hline 21. & Partai Nasional Indonesia & 377.137 & 1 & 108.162 \\
\hline 22. & Partai KAMI & 289.489 & 1 & 60.514 \\
\hline 23. & Partai Umat Islam & 269.309 & $1^{*}$ & - \\
\hline 24. & Partai Masyumi & 456.718 & $1^{*}$ & - \\
\hline 25. & PADI & 85.838 & $0^{*}$ & - \\
\hline 26. & Partai Masyumi Baru & 151.589 & 0 & - \\
\hline 27. & Partai Abul Yatama & 213.979 & 0 & 213.979 \\
\hline 28. & Partai Kebangsaan Merdeka & 104.385 & 0 & 104.385 \\
\hline 29. & Partai Rakyat Demokratik & 78.730 & 0 & 78.730 \\
\hline 30. & PSII 1905 & 152.787 & $0^{*}$ & 151.589 \\
\hline 31. & Partai Katolik Demokrat & 216.675 & 0 & 216.675 \\
\hline 32. & Partai Pilihan Rakyat & 40.517 & 0 & 40.517 \\
\hline 33. & Partai Rakyat Indonesia & 45.290 & 0 & 45.290 \\
\hline 34. & Partai Solidaritas Pekerja & 49.807 & 0 & 49.807 \\
\hline 35. & Partai Republik & 208.157 & 0 & 208.157 \\
\hline 36. & Partai Islam Demokrat & 62.901 & 0 & 62.901 \\
\hline 37. & Partai Murba & 62.006 & 0 & 62.006 \\
\hline 38. & PUDI & 140.980 & 0 & 140.980 \\
\hline 39. & Partai Buruh Nasional & 111.629 & 0 & 111.629 \\
\hline 40. & Partai MKGR & 204.204 & 0 & 204.204 \\
\hline
\end{tabular}




\begin{tabular}{|l|l|l|l|l|}
\hline 41. & Partai Cinta Damai & 168.087 & 0 & 168.087 \\
\hline 42. & Partai SPSI & 61.095 & 0 & 61.095 \\
\hline 43. & PNBI & 149.136 & 0 & 149.136 \\
\hline 44. & Partai SUNI & 180.167 & 0 & 180.167 \\
\hline 45. & Partai Nasional Demokrat & 96.984 & 0 & 96.984 \\
\hline 46. & $\begin{array}{l}\text { Partai Umat Muslimin } \\
\text { Indonesia }\end{array}$ & 49.839 & 0 & 49.839 \\
\hline 47. & Partai Pekerja Indonesia & 63.930 & 0 & 63.930 \\
\hline 48. & Partai Indonesia Baru & 192.712 & 0 & 192.712 \\
\hline JUMLAH & & 440 & \\
\hline
\end{tabular}

Ket:

* : Partai-partai yang melakukan stembusaccord

- : Sisa suara yang telah habis dibagi

Dalam pembagian ini, masih tersisa 22 kursi, kemungkinan yang terjadi adalah:

1. Partai-partai yang tidak mendapatkan kursi memberikan suaranya "melalui mekanisme tertentu" (mekanisme tertentu ini bisa berarti perjanjian politik antar partai) kepada partaipartai besar seperti Golkar, PPP, PAN, dan lain-lain. Dengan rincian jumlah suara partai yang tidak mendapat kursi sebesar $=12$ buah kursi

2. Sisa-sisa suara dari partai yang mendapat kursi digabungkan dan diberikan kepada partai-partai tertentu "melalui mekanisme tertentu". Dengan rincian jumlah sisa suara partai yang mendapatkan kursi sebesar $=10$ buah kursi. Total kursi dari yang mendapat kursi ditambah dengan sisa suara partai berjumlah 22 kursi, yang diberikan kepada:

a. Golkar: 7 Kursi (Penggabungan dari Partai: PIB, PKM, PR, PM, PMKGR, PNBI, PND, dan lainnya)

b. PPP: 9 Kursi (dari penggabungan partai: PUMI, PMB, Partai Abul Yatama, Dan lainnya)

c. PAN: 3 Kursi

d. PDKB: 1 Kursi 
e. PMU: 1 Kursi

f. PBTI: 1 Kursi

Sehingga kursi akhir : (Tabel 2.2)

\begin{tabular}{|c|c|c|}
\hline No & Nama Partai & Kursi \\
\hline 1. & PDI Perjuangan & 155 \\
\hline 2. & Partai Golongan Karya & 103 \\
\hline 3. & Partai Persatuan Pembangunan & 58 \\
\hline 4. & Partai kebangkitan Bangsa & 58 \\
\hline 5. & Partai Amanat Nasional & 35 \\
\hline 6. & Partai Bulan Bintang & $13^{*}$ \\
\hline 7. & Partai Keadilan & $6^{*}$ \\
\hline 8. & Partai Keadilan dan Persatuan & 4 \\
\hline 9. & Partai Demokrasi Kasih Bangsa & $3^{*}$ \\
\hline 10. & Partai Nahdlatul Umat & $3^{*}$ \\
\hline 11. & Partai Bhinneka Tunggal Ika & $3^{*}$ \\
\hline 12. & Partai Demokrasi Indonesia & 2 \\
\hline 13. & Partai Kebangkitan Umat & $1^{*}$ \\
\hline 14. & Partai Serikat Islam Indonesia & 1 \\
\hline 15. & PNI Front Marhaenis & 1 \\
\hline 16. & Partai IPKI & 1 \\
\hline 17. & PNI Massa Marhaen & 1 \\
\hline 18. & Parati Persatuan & 2 \\
\hline 19. & Partai Daulat Rakyat & 1 \\
\hline 20. & Partai Kristen Nasional & 1 \\
\hline 21. & Partai Nasional Indonesia & 1 \\
\hline 22. & Partai KAMI & 1 \\
\hline 23. & Partai Umat Islam & $1^{*}$ \\
\hline 24. & Partai Masyumi & $0^{*}$ \\
\hline 25. & PADI & $0 *$ \\
\hline 26. & Partai Masyumi Baru & 0 \\
\hline 27. & Partai Abul Yatama & 0 \\
\hline 28. & Partai Kebangsaan Merdeka & 0 \\
\hline 29. & Partai Rakyat Demokratik & 0 \\
\hline 30. & PSII 1905 & $0 *$ \\
\hline 31. & Partai Katolik Demokrat & 0 \\
\hline 32. & Partai Pilihan Rakyat & 0 \\
\hline
\end{tabular}




\begin{tabular}{|l|l|l|}
\hline 33. & Partai Rakyat Indonesia & 0 \\
\hline 34. & Partai Solidaritas Pekerja & 0 \\
\hline 35. & Partai Republik & 0 \\
\hline 36. & Partai Islam Demokrat & 0 \\
\hline 37. & Partai Murba & 0 \\
\hline 38. & PUDI & 0 \\
\hline 39. & Partai Buruh Nasional & 0 \\
\hline 40. & Partai MKGR & 0 \\
\hline 41. & Partai Cinta Damai & 0 \\
\hline 42. & Partai SPSI & 0 \\
\hline 43. & PNBI & 0 \\
\hline 44. & Partai SUNI & 0 \\
\hline 45. & Partai Nasional Demokrat & 0 \\
\hline 46. & Partai Umat Muslimin Indonesia & 0 \\
\hline 47. & Partai Pekerja Indonesia & 0 \\
\hline 48. & PPartai Indonesia Baru & 0 \\
\hline JUMLAH & 462 \\
\hline
\end{tabular}

Apabila penghitungan suara dilakukan tanpa menggunakan sistem stembusaccord maka perolehan suara (dan hasil ini yang digunakan oleh KPU untuk memperoleh kursi) adalah sebagai berikut:

(Tabel 2.3)

\begin{tabular}{|l|l|l|l|}
\hline No & \multicolumn{1}{|c|}{ Nama Partai } & Perolehan Suara & Kursi \\
\hline 1. & PDI Perjuangan & 35.689 .073 & 153 \\
\hline 2. & Partai Golongan Karya & 23.741 .758 & 120 \\
\hline 3. & Partai Persatuan Pembangunan & 11.329 .905 & 58 \\
\hline 4. & Partai kebangkitan Bangsa & 13.336 .982 & 51 \\
\hline 5. & Partai Amanat Nasional & 7.528 .956 & 34 \\
\hline 6. & Partai Bulan Bintang & 2.049 .708 & 13 \\
\hline 7. & Partai Keadilan & 1.936 .565 & 7 \\
\hline 8. & Partai Keadilan dan Persatuan & 1.065 .686 & 4 \\
\hline 9. & Partai Demokrasi Kasih Bangsa & 550.851 & 5 \\
\hline 10. & Partai Nahdlatul Umat & 658.063 & 5 \\
\hline 11. & Partai Bhinneka Tunggal Ika & 345.292 & 1 \\
\hline 12. & Partai Demokrasi Indonesia & 655.049 & 2 \\
\hline
\end{tabular}




\begin{tabular}{|c|c|c|c|}
\hline 13. & Partai Kebangkitan Umat & 300.064 & 1 \\
\hline 14. & Partai Serikat Islam Indonesia & 375.920 & 1 \\
\hline 15. & PNI Front Marhaenis & 363.397 & 1 \\
\hline 16. & Partai IPKI & 327.301 & 1 \\
\hline 17. & PNI Massa Marhaen & 345.720 & 1 \\
\hline 18. & Partai Persatuan & 550.808 & 1 \\
\hline 19. & Partai Daulat Rakyat & 429.854 & 1 \\
\hline 20. & Partai Kristen Nasional & 369.446 & 1 \\
\hline 21. & Partai Nasional Indonesia & 377.137 & 1 \\
\hline 22. & Partai KAMI & 289.489 & 0 \\
\hline 23. & Partai Umat Islam & 269.309 & 0 \\
\hline 24. & Partai Masyumi & 456.718 & 0 \\
\hline 25. & PADI & 85.838 & 0 \\
\hline 26. & Partai Masyumi Baru & 151.589 & 0 \\
\hline 27. & Partai Abul Yatama & 213.979 & 0 \\
\hline 28. & Partai Kebangsaan Merdeka & 104.385 & 0 \\
\hline 29. & Partai Rakyat Demokratik & 78.730 & 0 \\
\hline 30. & PSII 1905 & 152.787 & 0 \\
\hline 31. & Partai Katolik Demokrat & 216.675 & 0 \\
\hline 32. & Partai Pilihan Rakyat & 40.517 & 0 \\
\hline 33. & Partai Rakyat Indonesia & 45.290 & 0 \\
\hline 34. & Partai Solidaritas Pekerja & 49.807 & 0 \\
\hline 35. & Partai Republik & 208.157 & 0 \\
\hline 36. & Partai Islam Demokrat & 62.901 & 0 \\
\hline 37. & Partai Murba & 62.006 & 0 \\
\hline 38. & PUDI & 140.980 & 0 \\
\hline 39. & Partai Buruh Nasional & 111.629 & 0 \\
\hline 40. & Partai MKGR & 204.204 & 0 \\
\hline 41. & Partai Cinta Damai & 168.087 & 0 \\
\hline 42. & Partai SPSI & 61.095 & 0 \\
\hline 43. & PNBI & 149.136 & 0 \\
\hline 44. & Partai SUNI & 180.167 & 0 \\
\hline 45. & Partai Nasional Demokrat & 96.984 & 0 \\
\hline 46. & Partai Umat Muslimin Indonesia & 49.839 & 0 \\
\hline 47. & Partai Pekerja Indonesia & 63.930 & 0 \\
\hline 48. & Partai Indonesia Baru & 192.712 & 0 \\
\hline
\end{tabular}


Partai politik yang berhak memperoleh kursi di parlemen hanya 19 partai, hasil ini menunjukan bahwa terdapat selisih 2 partai yang mendapat kursi dari sistem stembusaccord yang mengalokasikan 23 partai politik untuk mendapatkan kursi di parlemen. Dengan tidak digabungkannya sisa suara, maka dalam penghitungan tanpa stembusaccord, sisa suara dari partai politik yang tidak mencapai BPP dinyatakan hangus.

Dari hasil pemilu legislatif tahun 1999 ini terdapat banyak kelemahan dalam penghitungan Sistem sisa suara terbanyak pada tahun 1999, karena dari hasil perhitungan dengan sistem sisa suara terbanyak didapat perolehan jumlah kursi di parlemen (DPR) berbeda dengan jumlah kursi yang sebenarnya di DPR. Ini juga yang menghalangi pembagian kursi dengan menggunakan metode di atas untuk implementasi perolehan kursi di Parlemen pada tahun 1999. Hal ini bisa terjadi karena beberapa hal, antara lain:

1. Sistem perhitungan di Indonesia tidak dengan murni menerapkan sistem sisa suara terbanyak, contohnya PKB yang jumlah suara lebih besar dibandingkan dengan PPP mendapatkan kursi yang lebih sedikit, karena penerapan sistem pembagian kursi berdasarkan daerah (jatah kursi berbeda untuk setiap daerah). Hal ini makin membuktikan bahwa metode perhitungan ilmiah yang diterapkan dalam penyelesaian fakta, perlu penyesuaian.

2. Tidak lengkapnya informasi (menyebabkan pengolahan data tidak dapat dilakukan secara lebih tepat dan akurat) perhitungan ini belum mengakomodasikan sistem proporsional pada tingkat propinsi, juga teknologi yang masih minim, serta carut-marut perkembangan situasi politik nasional pada 1999 mendesak PPI, KPU, Partai Politik, maupun lembaga lainnya untuk bertindak buru-buru dalam melakukan penyelesaian sengketa hasil pemilu. ${ }^{46}$ 


\section{Analisis dan Perbandingan Undang-Undang Nomor 3 Tahun 1999 tentang Pemilihan Umum dengan Keputusan Mahkamah Konstitusi terhadap Pelaksanaan Stembusaccord}

Dalam tataran ideal, Pemilihan Umum diadakan untuk menciptakan Representative Government (pemerintah yang representatif ${ }^{47}$ ). Sebuah pemilu yang demokratis, dapat diidentifikasi dengan melihat sejauh mana "pertarungan antarkelompok" terekspresikan. Sehingga manakala sebuah pemilu kehilangan sisi kompetitifnya, maka ia pun menjadi sebuah ritual politik semu yang hanya berguna untuk mencari legitimasi semata. ${ }^{48}$ Sebab, hakikat dari pemilu tiada lain dari kompetisi.

Dalam mewujudkan pelaksanaan Pemilu tersebut, maka diperlukan suatu aturan yang mengatur ke-terlaksanaannya agar dapat sesuai dengan cita- cita keterwakilan rakyat sebagai jalan kedaulatan rakyat. Seperti dijelaskan pada bab sebelumnya, pada Pemilu pertama pasca Orde Baru, yaitu era transisi reformasi tahun 1999 ditandai dengan semangat demokratisasi yang diwarnai dengan era kebebasan dan penolakan terhadap semua hal yang berhubungan dengan Orde Baru.

Pemilu pertama tahun 1999 ini terlaksana dengan aturan yang terkesan memang terburu-buru mengingat desakan dari banyak pihak agar terlaksananya Pemilu telah sampai pada puncaknya. ${ }^{49}$ Untuk itu tersusunlah Undang-Undang Nomor 3 Tahun 1999 Tentang Pemilihan Umum yang terdiri dari 86 Pasal $^{50}$ yang memuat berbagai macam aturan mengenai Pemilu legislatif tahun 1999.

Pemilu tahun 1999 menggunakan sistem stelsel terdaftar, dimana konstituen hanya memilih partai politik saja dan

\footnotetext{
47 Representatif berarti dapat mewakili sesuai dengan fungsinya sebagai wakil. Sedangkan perbuatannya (mewakili) disebut representasi. Lihat, Tim Pusat Bahasa Departemen Pendidikan Nasional, Kamus Besar Bahasa Indonesia, Edisi III, (Jakarta: Balai Pustaka, 2008), 950

${ }^{48}$ Eep Saefulloh Fatah, Catatan Atas Gagalnya Politik Orde Baru, (Yogyakarta: Pustaka Pelajar, 1998), |00-10 |

${ }^{49}$ Ibid., 101

${ }^{50}$ Undang-Undang Nomor 3 Tahun 1999 Tentang Pemilihan Umum.
} 
selanjutnya partai politik yang akan menentukan siapa wakil dari partai tersebut yang akan mewakilinya di parlemen. Sistem ini biasa terdapat pada proporsional representation atau sistem perwakilan berimbang dan diakui memiliki banyak kelebihan dibanding sistem yang lain. Misal, tidak adanya suara pemilih yang hilang dan diabaikan dalam mekanisme pemilihan wakil rakyat yang akan terpilih. Sehingga, sistem ini sering dikatakan lebih demokratis. Namun, di balik keunggulannya, terdapat juga kekurangan, seperti: cara perhitungan yang rumit, dan cenderung mengutamakan peranan partai politik daripada para wakil rakyat secara langsung. ${ }^{51}$

Dalam perihal penggabungan sisa suara hasil pemilu atau stembusaccord, memang tidak secara eksplisit diterangkan dan tertera serta diatur dalam Undang-Undang Nomor 3 Tahun 1999, akan tetapi diatur dalam Peraturan Pemerintah Nomor 33 Tahun 1999 Tentang Pelaksanaan Undang-Undang Nomor 3 Tahun 1999 Tentang Pemilihan Umum Dalam pasal 36 pada ayat 1 sampai 3.

(1) Dua atau lebih Partai Politik Peserta Pemilu dapat mengikatkan diri dalam kesepakatan tentang Penggabungan suara di daerah Tingkat I dan Tingkat II untuk penentuan calon terpilih anggota DPR, DPRD I Propinsi, dan DPRD II Kota/Kabupaten.

(2) Kewenangan melakukan kesepakatan sebagaimana dimaksud dalam ayat (1) berada pada Dewan Pimpinan Pusat Partai Politik Peserta Pemilu dan kewenangan tersebut dapat didelegasikan kepada Dewan Pimpinan Daerah Partai Politik yang bersangkutan.

(3) Kesepakatan sebagaimana dimaksud dalam ayat (1) sudah harus diumumkan selambat-lambatnya 7 (tujuh) hari sebelum pemungutan suara dan tembusannya disampaikan kepada PPI, PPD I, PPD II, dan PANWAS sesuai dengan tingkatannya.

51 Pataniari Siahaan, Politik Hukum Pembentukan Undang-undang: Pasca Amandemen Konstitusi UUD 1945, (Jakarta: Konpress, 20 I2), 131 
Apabila dicermati, tidak diaturnya stembusaccord secara eksplisit dalam Undang-Undang Nomor 3 Tahun 1999 dapat dikatakan disebabkan oleh singkatnya interval waktu pembuatan Undang-undang yang hanya berjalan beberapa bulan dengan Pemilu yang dilaksanakan hanya 13 bulan sejak masa kekuasaan Presiden Habibie. Walaupun telah dibentuk Tim Ahli yaitu Tim Tujuh dengan ketua Ryas Rasyid sebagai pakar, namun memang harus diakui, singkatnya waktu juga ikut mempengaruhi proses pembuatan Undang-Undang yang meliputi perencanaan, persiapan, teknik penyusunan, perumusan, pembahasan, pengesahan, pengundangan, dan penyebarluasan. ${ }^{52}$

Untuk mengantisipasi hal tersebut, dalam pasal 84 UndangUndang Nomor 3 Tahun 1999 dicantumkan aturan secara implisit apabila dalam perkembangan situasi pra-pemilu diperlukan aturan mengenai stembusaccord.

"Segala sesuatu yang belum cukup diatur di dalam UndangUndang ini (UU Nomor 3, Pen), Pasal diatur dengan Peraturan Pemerintah sesuai kebutuhan" 53

Undang-undang Nomor 3 Tahun 1999 merupakan aturan induk yang mengatur tentang pemilu legislatif pada tahun 1999, namun akibat dari perkembangan awal reformasi yang secara cepat berubah, maka diperlukan aturan lain sebagai pelaksana teknis Undang-undang Nomor 3 tersebut. Seperti dalam konsideran Peraturan Pemerintah Nomor 33 yang menyatakan sebagai berikut:

"Bahwa untuk melaksanakan ketentuan pasal 84 Undangundang Nomor 3 tentang Pemilihan Umum, perlu menetapkan Peraturan Pemerintah tentang Pelaksanaan undang-undang Nomor 3 tahun 1999 tentang Pemilihan Umum."

Ketentuan ini juga diperjelas oleh UUD Tahun 1945 sebelum amandemen pada pasal 5 ayat 2 yang menyatakan:

\footnotetext{
52 lbid., 356

${ }^{53}$ Pasal 84 Peraturan Pemerintah Nomor 33 Tahun 1999.
} 
"Presiden menetapkan Peratuan Pemerintah untuk menjalankan Undang-undang sebagaimana mestinya"

Dapat dikatakan, ketentuan yang tertera dalam Peraturan Pemerintah Nomor 33 tersebut di atas telah saling mendukung dengan ketentuan Peraturan perundang-undangan di atasnya, dan juga telah sesuai dengan ketentuan yang tertera pada UUD. Hal ini disebut dengan teori hierarki Peraturan Perundang-undangan yang menyatakan bahwa norma ${ }^{54}$ yang lebih rendah tidak boleh bertentangan dengan norma yang lebih tinggi. Menurut teori ini, materi peraturan Perundang-undangan tersusun secara hierarki dan Undang-undang Dasar berada di puncaknya. Teori ini dikemukakan oleh Adolf Merkel sebagai kerangka berpikir untuk teori jenjang norma hukum, dimana norma dasar menjadi tempat bergantungnya serta menjadi sumber hukum norma-norma di bawahnya. 55

Sebenarnya, Undang-Undang telah jelas menyatakan keteraturan stembusaccord sebagaimana dijelaskan di atas, namun akibat pertentangan politik yang belum sehat karena melibatkan banyak sekali partai politik, pertarungan kepentingan menjadi penguasa $^{56}$ membuat ketentuan stembusaccord terabaikan. Ini terbukti dari tereduksinya kesepakatan stembusaccord dalam pembagian kursi di parlemen pusat. Terlebih lagi mayoritas anggota KPU merupakan perwakilan Partai politik yang membuat proses pembagian kursi syarat kepentingan partai. Padahal, hampir sebagian besar daerah tingkat I dan II telah

\footnotetext{
${ }^{54}$ Norma atau Kaidah merupakan pelembagaan nilai-nilai baik dan buruk dalam bentuk tata aturan yag berisi kebolehan, anjuran, perintah. Baik anjuran maupun perintah dapat berisi kaidah yang bersifat positif atau negatif sehingga mencakup norma anjuran untuk mengerjakan sesuatu atau tidak mengerjakan sesuatu, dan norma perintah untuk melakukan atau perintah untuk tidak melakukan. Lihat, Jimly Asshiddiqqie, Perihal Undang-undang, (Jakarta: Konstitusi Press, 2006), 5

${ }^{55}$ Pataniari Siahaan, Politik Hukum., 320

${ }^{56}$ Azyumardi Azra mengistilahkan masa politik 1999 ini sebagai masa All Generals, No Indians: Semua ingin jadi Jenderal (penguasa), tidak ada yang ingin jadi 'Indian' alias anak buah. Lihat Andina Dwifatma, Cerita Azra: Biografi Cendekiawan Muslim Azyumardi Azra, Jakarta: Erlangga, 201 I), 105
} 
mengimplementasikannya sebagai pedoman pembagian kursi. Hal ini ditambah oleh belum terbentuknya Mahkamah Konstitusi yang berguna sebagai tempat pengujian Undang-undang dan sengketa partai politik sehingga Keputusan akhir dan final pada pemilu 1999 sepenuhnya tergantung pada keputusan KPU.

Tereduksinya ketetapan stembusaccord pada pemilu 1999 juga telah melanggar hak konstitusional warga negara dimana amanat UUD 1945 sebelum Amandemen menyatakan kedaulatan ada di tangan rakyat (Pasal 1 Ayat 2), juga telah melanggar Pasal 27 Ayat 1 UUD 1945 Sebelum Amandemen yang berbunyi:

"Segala warga negara bersamaan kedudukannya di dalam hukum dan pemerintahan dan wajib menjunjung hukum dan pemerintahan itu dengan tidak ada kecualinya"

Sebagai perbandingan, dalam perkembangan pasca reformasi, berbagai perbaikan dalam Pemilihan Umum menjadi salah satu agenda yang di kedepankan pemerintah Indonesia, salah satunya dengan membentuk Mahkamah Konstitusi pada tahun 2003 untuk memutus sengketa Partai Politik termasuk mengenai pengujian Undang-Undang terhadap Undang-Undang Dasar. Pada tahun 2009, setelah terdapat ketentuan uji materill terhadap UndangUndang dan terjadi perbedaan penafsiran mengenai sisa hasil suara pada pemilu tahun 2009 antara KPU dan badan peserta Pemilu lainnya, maka MK memutuskan untuk membatalkan ketentuan sisa hasil suara terhadap pemilu-pemilu yang akan datang. Seperti diketahui bahwa berdasarkan peraturan KPU, yang dimaksud dengan sisa suara adalah suara sah yang diperoleh partai politik yang tidak mendapat kursi pada perhitungan tahap pertama dan tahap kedua. Sementara, bagi partai politik yang mendapat kursi pada perhitungan tahap pertama dan tahap kedua, sisa suara merupakan suara yang tersisa setelah dikurangi BPP. Terjadi perbedaan dengan dasar yang menjadi pegangan Mahkamah Konstitusi, dalam hal ini Mahkamah Konstitusi (MK) membatalkan keputusan Komisi Pemilihan Umum (KPU) tentang 
sistem penetapan caleg terpilih pada tahap ketiga (di tingkat provinsi).

Alasannya, penetapan caleg yang memperebutkan sisa kursi dengan menghitung sisa suara itu dianggap tidak sesuai dengan UU Nomor 10 Tahun 2008 tentang Pemilu.Sebelumnya, sesuai Keputusan KPU Nomor 255/2009, memutuskan bahwa caleg yang memperebutkan sisa kursi diperoleh dari penghitungan sisa suara di dapil yang memiliki sisa suara.Dalam putusannya, MK menyatakan telah terjadi perbedaan penafsiran antara para pemohon dan KPU atas penerapan pasal 205 ayat (5), (6), dan (7) tersebut. ${ }^{57}$ Dinamika perdebatan seperti ini memang menjadi hal yang tidak dapat dihindari antar lembaga negara dalam proses reformasi dan demokratisasi. Namun terlepas dari itu semua, dengan jelas ikut terlibat dalam pemilihan umum sebagai jalan kedaulatan ada di tangan rakyat merupakan sepenuhnya hak rakyat dan warga negara yang suaranya tidak bisa 'dihanguskan' dalam sistem pembagian kursi. Salah satu cara menyelamatkannya adalah kebijakan penerapan sistem stembusaccord.

\section{Analisis Pelaksanaan Stembusaccord pada Pemilu Legislatif 1999 menurut Undang-Undang Nomor 3 Tahun 1999 dalam Perspektif Fiqh Siyasah}

Pemimpin adalah wakil umat untuk menangani kepentingan agama dan dunia selaras dengan perintah Allah dan Rasul-Nya. Oleh sebab itu, kekuasaannya bersumber pada umat. Apabila pemimpin berbuat salah, umat mempunyai hak untuk menasehati, meluruskan, dan mengoreksi, bahkan mempunyai hak untuk memecat bila terdapat alasan yang sah untuk bertindak demikian. Maka adalah logis kalau sumber kekuasaan tetap pada pemberi mandat (umat), bukan pelaksana mandat. ${ }^{58}$

Karena pemberi mandat adalah umat, maka umat memiliki hak untuk memilih dan menentukan wakilnya di pemerintahan.

${ }^{57} \mathrm{http}: / / \mathrm{w} w \mathrm{w}$. hariansumutpos.com/arsip/?p=909, (diakses 19 Februari 2014)

${ }^{58}$ M. Yusuf Musa, Politik dan Negara dalam Islam, (Al-Ikhlas: Surabaya, 1990), 135 
Karena negara yang Islami adalah memberikan perlakuan dan penghormatan terhadap hak-hak dan kebebasan manusia sebagai penentu bagi kemuliaan umat.

Di negara modern, realisasi kedaulatan tersebut terletak pada pelaksanaan Pemilihan Umum yang melibatkan seluruh rakyat dalam suatu negara yang berguna untuk menentukan siapa yang berhak mewakili mereka di dalam perjalanan pemerintahan. Setelah diadakannya pemilihan, maka ditentukan berapa wakil yang akan mewakili rakyat tersebut. Dalam konteks Indonesia, sistem perwakilan rakyat merupakan pelaksana kedaulatan rakyat sebagaimana amanat Undang-undang. Maka, apabila dalam suatu pemilihan umum tidak mewakili suara rakyat, pemilihan umum tersebut tidak dapat dikatakan sah.

Dalam pemilihan umum, apabila penggabungan sisa suara hasil pemilu diabaikan, maka otomatis suara rakyat dan peran sertanya dalam mandat pemberi kekuasaan menjadi hilang, dan dapat dikatakan kekuasaan yang terbentuk tidak dapat mewakili sepenuhnya keinginan rakyat karena kursi yang ada di parlemen akan berkurang, ${ }^{59}$ dan itu otomatis juga dapat mengurangi konversi suara rakyat yang terkumpul untuk menempatkan wakilnya di pemerintahan.

Dampak pelaksanaan sistem stembusaccord, selain memiliki dampak pemberdayaan umat juga memiliki peran PolitikKeagamaan yang setidaknya ada enam: pertama, meminimalisasi terjadinya kemubaziran sisa suara. setelah stembusaccord dilaksanakan, ada kemungkinan malah menambah jatah kursi. Kedua, stembusaccord sendiri sebenarnya sudah merupakan bukti solidaritas antar partai. Ketiga, memanfaatkan wewenang partai untuk memilih figur pemersatu untuk mewakili kursi stembusaccord sehingga proses wihdah al-ummah (satu umat) bisa lebih mudah dijembatani. Keempat, lebih jauh bisa mewujudkan fraksi Islam di lembaga legislatif. Kelima, stembusaccord akan

${ }^{59}$ Muhakki, Mekanisme Suara.., 165

\begin{tabular}{l|l}
555 & al-Daulah \\
Vol. 5. no.2. Oktober 2015
\end{tabular} 
menaikkan bobot wibawa politik umat Islam, karena suara-suara umat sudah terdengar amat gusar mengkritik banyaknya partai Islam, sehingga stembusaccord adalah salah satu wujud harapan tersebut. Keenam, umat Islam bisa memainkan peran oposisi. Karena itu fungsi utamanya lebih sebagai kekuatan check and balances. ${ }^{60}$

Pemberdayaan ummat yang dikenal dengan hifz al-ummah, yaitu: hifz al-nafs, akan sepenuhnya memenuhi amanat rakyat sebagai pemberi mandat. Oleh karena itu, semua rakyat dan warga negara berhak mendapatkan jaminan terhadap hak-hak asasi manusia (hurriyah al-syakhsiyyah), jaminan mengeluarkan pendapat (hurriyah al-ra'y), dan hak untuk mendapatkan persamaan (almusawah) di muka hukum dan pemerintahan. ${ }^{61}$

Dalam hal ini, Buya Hamka menyatakan bahwa persamaan adalah hak segenap manusia. Karena kejadian manusia itu sama, maka keperluan hidup juga sama. Maka mereka harus mendapatkan hak yang sama dalam hidup dan di muka Undangundang. ${ }^{62}$

Hamka melanjukan, dalam realisasi Hak-hak Asasi manusia dan hak mengemukakan pendapat, yang harus diingat adalah bahwa kemerdekaan memiliki tiga pokok: pertama, merdeka iradah (kemauan), yaitu bebas memerintah, menyuruh, menyarankan, dan menganjurkan, dan menciptakan hal-hal yang ma'ruf (baik). Kedua, merdeka pikiran, bebas menyatakan pikiran, yaitu melarang, menahan, memperotes, mengoposisi yang munkar, yang ditentang oleh masyarakat. Ketiga, kemerdekaan jiwa, yaitu bebas dari rasa takut akan berbagai macam gangguan. ${ }^{63}$

\footnotetext{
${ }^{60}$ Husin M. al-Banjari, "Stembusaccord 'Malaikat Penyelamat' Partai Islam," dalam Deliar Noer (et. al), Ed. Hamid Basyaib, Hamid Abidin, Mengapa Partai Islam Kalah?: Perjalanan Politik Islam dari Pra-Pemilu '99 Sampai Pemilihan Presiden, (Jakarta: Alvabet, 1999), 205-207

${ }_{61}$ Muhakki, Mekanisme Suara.., 165

62 Shobahussurur, DKK, Mengenang 100 Tahun Haji Abdul Malik Karim Amarullah (HAMKA), (Jakarta: YPI Al-Azhar, 2008), I 49

${ }^{63}$ lbid., I 49
} 
Dengan demikian, dengan dilaksanakannya stembusaccord, terlepas dari tidak diimplementasikannya sistem ini pada akhir pembagian kursi di pemilu legislatif 1999, akan mengurangi efek negatif pecahnya umat Islam sebagai konstituen partai Islam dan akan mengurangi hak-hak umat Islam sebagai mayoritas di Indonesia, serta akan menjamin kualitas keterwakilan aggota parlemen. Sedangkan apabila tidak terealisasi, akan melahirkan efek negatif terhadap rakyat secara umum yang berdampak pada pemangkasan terhadap hak-hak rakyat, dan pembatasan kepada kebebasan warga negara untuk dipilih dan memilih.

\section{Penutup}

Berdasarkan penelitian di atas, diketahui bahwa mekanisme pelaksanaan stembusaccord pada pemilu legislatif tahun 1999 menurut Undang-Undang Nomor 3 tahun 1999 adalah sebagai berikut:

a) Dua atau lebih Partai Politik mengadakan sebuah kesepakatan mengenai penggabungan sisa suara hasil pemilu.

b) Kewenangan dalam penentuan kesepakatan penggabungan tersebut ditentukan oleh Dewan Pimpinan Pusat Partai yang bertempat di Ibu Kota Negara serta dapat mendelegasikannya kepada Dewan Pimpinan Daerah Partai Politik yang bersangkutan.

c) Kesepakatan tersebut harus dilakukan sebelum pemungutan suara berlangsungdan sudah harus diumumkan selambatlambatnya 7 (tujuh) hari sebelum pemungutan suara dan tembusannya disampaikan kepada PPI, PPD I, PPD II, dan PANWAS sesuai dengan tingkatannya.

d) Sesuai dengan Rapat Pleno KPU pada Bulan Mei 1999, kesepakatan Stembusaccord berbentuk "SK" (Surat Keputusan) yang dibuat oleh masing-masing Partai Politik yang melakukan Stembusaccord dan harus ditandatangani oleh ketua Umum dan Sekjen (Sekretaris Jenderal) masing-masing partai sebelum diserahkan kepada KPU. 
e) Setelah berkas diterima dan dinyatakan telah sesuai dengan syarat-syarat Stembusaccord oleh KPU, maka partai politik yang telah bersepakat dapat mengimplementasikan Stembusaccord hasil kesepakatan tersebut setelah pemilu dilaksanakan pada proses penghitungan sisa suara.

f) Pada proses penghitungan sisa suara, sisa suara yang dilimpahkan itu lazimnnya setelah pembagian kursi tahap pertama usai berdasarkan Bilangan Pembagi Pemilih (BPP).

g) Setelah penghitungan sisa suara, dalam kesepakatan ini, partai dengan suara sah terbanyak dari partai-partai yang melakukan Stembusaccord tadilah yang berhak menerima tambahan suara.

h) Sisa suara dari partai politik yang mengadakan stembusaccord itu akan menambah jumlah kursi bagi partai politik yang pada pembagian pertama tidak mendapat kursi, atau mendapat jumlah kursi yang kecil, ataupun sisa suara dari partai yang kecil diberikan kepada partai yang mendapat kursi banyak supaya menambah jumlah kursinya, tergantung pada kesepakatan antar partai politik dalam kesepakatan stembusaccord tersebut.

Dalam pandangan Islam, umat adalah sumber kedaulatan pemberi mandat kepada kepada para pemimpin, karena pemimpin merupakan wakil mereka di pemerintahan.dengan adanya stembusaccord maka hak-hakrakyat menjadi terpenuhi, hakhak tersebut seperti: Pemberdayaan ummat yang dikenal dengan hifz al-ummah, yaitu: hifz al-nafs, akan sepenuhnya memenuhi amanat rakyat sebagai pemberi mandat. Oleh karena itu, semua rakyat dan warga negara berhak mendapatkan jaminan terhadap hak-hak asasi manusia (hurriyah al-syakhsiyyah), jaminan mengeluarkan pendapat (hurriyah al-ra'y), dan hak untuk mendapatkan persamaan (al-musyawah) di muka hukum dan pemerintahan. 


\section{Daftar Pustaka}

Aspinal, Edward dan Marcus Mitzner, ed., Problems of Democratisation in Indonesia; Election, Institutions and Society. Singapore: Institute of Southeast Asian Studies, 2010.

Asshiddiqqie, Jimly. Perihal Undang-Undang. Jakarta: Konstitusi Press, 2006.

Banjari (al-), Husin M. "Stembusaccord 'Malaikat Penyelamat' Partai Islam," dalam Deliar Noer (et. al), Ed. Hamid Basyaib, Hamid Abidin. Mengapa Partai Islam Kalah?: Perjalanan Politik Islam dari Pra-Pemilu '99 Sampai Pemilihan Presiden. Jakarta: Alvabet, 1999.

Budiarjo, Miriam. Dasar-dasar Ilmu Politik. Jakarta: PT. Gramedia Pustaka Utama, 2008.

Dwifatma, Andina. Cerita Azra: Biografi Cendekiawan Muslim Azyumardi Azra. Jakarta: Erlangga, 2011.

Fadjar, A. Mukhtie. Partai Politik dalam Perkembangan Ketatanegaraan Indonesia. Malang: Setara Press, 2012.

Fatah, Eep Saefulloh. Catatan Atas Gagalnya Politik Orde Baru. Yogyakarta: Pustaka Pelajar, 1998.

Goris Seran, Gotfridus. Kamus Pemilu Populer. Yogyakarta: Graha Ilmu, 2013.

http://www.hariansumutpos.com/arsip/?p=909, diakses 19 Februari 2014.

Ibrahim, Jimmi Mohammad. "Kalbar Pasca Pemilu". dalam http://www.reocities.com/Area51/Vault/1534/juni/08/berita370 36.htm diakses 27 Desember 2013.

Komunitas Informasi Terbuka, "runyamnya stembusaccord," dalam http://www.minihub.org/siarlist/msg03428.html diakses 27 Desember 2012.

Koran Republika, 1 Juli 1999 http:/groups.yahoo.com/neo/ groups/Freemail/conversations/topics/2779, diakses 27 Desember 2013 
Maridjan, Kacung. Sistem politik Indonesia: Konsolidasi Demokrasi Pasca-Orde Baru. Jakarta: Kencana, 2010.

Marimin. Teknik dan Aplikasi pengambilan Keputusan kriteria Majemuk. Jakarta: Grasindo, 2005.

Muhakki. "Mekanisme Suara Terbanyak Bagi Pemilu Legislatif". Dalam Jurnal al-Daulah, Vol. 01 Nomor 02, Oktober 2011.

Musa, M. Yusuf. Politik dan Negara dalam Islam. Al-Ikhlas: Surabaya, 1990.

Peraturan Pemerintah Nomor 33 Tahun 1999 Tentang Pelaksanaan Undang-Undang Nomor 3 tahun 1999 Tentang Pemilihan Umum.

Platzdasch, Bernhard. Islamism in Indonesia: Politics in the Emerging Democracy. Singapore: Institute of Southeast Asian Studies, 2009. http://www.amazon.com/Islamism-Indonesia-PoliticsEmerging-Democracy/dp/9814279099, diakses 17 Januari 2014

Puspoyo, Widjanarko. Dari Soekarno Hingga Yudhoyono: Pemilu Indonesia 1955-2009. Solo: Era Adicitra Intermedia, 2012.

Shobahussurur, DKK. Mengenang 100 Tahun Haji Abdul Malik Karim Amarullah (HAMKA). Jakarta: YPI Al-Azhar, 2008.

Siahaan, Pataniari. Politik Hukum Pembentukan Undang-undang: Pasca Amandemen Konstitusi UUD 1945. Jakarta: Konpress, 2012.

Tim Pusat Bahasa Departemen Pendidikan Nasional. Kamus Besar Bahasa Indonesia. Edisi III, Jakarta: Balai Pustaka, 2008.

Tutik, Titik Triwulan. Konstruksi Hukum Tata Negara Indonesia Pasca Amandemen UUD 1945. Jakarta: Kencana, 2011.

Undang-Undang Dasar Negara Republik Indonesia Tahun 1945 Undang-Undang Nomor 2 Tahun 1999 Tentang Partai Politik Undang-Undang Nomor 3 Tahun 1999 Tentang Pemilihan Umum Undang-Undang Nomor 4 Tahun 1999 Tentang Susunan dan Kedudukan Majelis Permusyawaratan Rakyat, Dewan Perwakilan Rakyat, Dewan Perwakilan Rakyat Daerah 